\title{
Helicobacter pylori related hypergastrinaemia is the result of a selective increase in gastrin 17
}

\author{
G Mulholland, J E S Ardill, D Fillmore, R S Chittajallu, G M Fullarton, K E L McColl
}

\begin{abstract}
Helicobacter pylori infection increases the serum concentration of gastrin, and this may be one of the mechanisms by which it predisposes to duodenal ulceration. Different forms of circulating gastrin were studied both basally and postprandially in 13 duodenal ulcer patients before and one month after eradication of $H$ pylori. Three antisera that are specific for particular regions of the gastrin molecules were used. Gel chromatography indicated that $>90 \%$ of the circulating gastrin consisted of gastrin (G) 17 and G34 both before and after eradicating the infection. The basal median total immunoreactive gastrin concentration fell from $26 \mathrm{pmol} / \mathrm{l}$ (range 11-43) to 19 $\mathrm{pmol} / \mathrm{l}(8-39)(p<0.05)$, entirely because of a fall in G17 from $6 \mathrm{pmol} / \mathrm{l}(<2 \cdot 4-25)$ to $<2.4$ $\mathrm{pmol} / \mathrm{l}(<2.4-23)(\mathrm{p}<0.001)$. The median (range) basal G34 values were similar before (15 pmol (2-36)) and after (10 pmol (2-30)) eradication. The median total immunoreactive gastrin concentration determined 20 minutes postprandially fell from $59 \mathrm{pmol} / 1$ (38-114) to $33 \mathrm{pmol} / \mathrm{l}(19-88)(\mathrm{p}<0.005)$, and again this was entirely the result of a fall in G17 from 43 $\mathrm{pmol} / \mathrm{l}(9-95)$ to $17 \mathrm{pmol} / \mathrm{l}(<2.4-52)(\mathrm{p}<0.001)$. The median postprandial G34 values were similar before (13 pmol/1, range 6-42) and after (15 pmol/l, range 6-30) eradication. Eating stimulated a noticeable rise in G17 but little change in G34, both in the presence and absence of $\boldsymbol{H}$ pylori. The finding that $H$ pylori infection selectively increases G17 explains why the infection causes mainly postprandial hypergastrinaemia. G17 is increased selectively because $H$ pylori predominantly affects the antral mucosa which is the main source of G17 whereas G34 is mainly duodenal in origin. This study also indicates that the increased concentration of gastrin in $\mathrm{H}$ pylori infection is the result of an increase in one of the main biologically active forms of the hormone. (Gut 1993; 34: 757-761)
\end{abstract}

University Department of Medicine and Therapeutics, Western Infirmary, Glasgow G11 6NT

R S Chittajallu G M Fullarton K E L McColl

Department of Medicine, Queen's University, Belfast

G Mulholland

JE S Ardill

D Fillmore

Correspondence to:

Dr K E L McColl.

basal concentrations are increased by app mately $50 \%$, and the integrated gastrin response to a meal is increased by approximately $100 \%$. The mechanism by which $H$ pylori infection increases serum gastrin is unknown but does not seem to be related to the bacterium's urease activity $^{7-9}$ or any effect of this on antral surface pH. ${ }^{10}$

The role of the increased serum gastrin concentration induced by $H$ pylori in the pathogene- sis of duodenal ulcer disease is also unknown. Studies to date have produced conflicting evidence concerning changes in acid secretion after eradication of $H$ pylori and lowering of the serum gastrin concentration..$^{231112}$ The reason for this is unclear. One possible explanation is that the increased immunoreactive gastrin circulating in patients with $H$ pylori infection is of reduced biological activity or indeed not biologically active at all.

It is established that gastrin circulates in at least four bioactive forms, component $I,{ }^{13}$ gastrin (G) $34,{ }^{14} \mathrm{G} 17,{ }^{15}$ and $\mathrm{G} 14 .{ }^{16}$ It has been suggested by Akai et $a l^{17}$ that some gastrin may be produced by an alternative processing route, which may involve other intermediate forms. Kothary $e t a l^{18}$ have reported that terminally extended forms of gastrin in conjunction with G14 are more prevalent in duodenal ulcer patients. Other fragments including $\mathrm{N}$-terminal fragments of $\mathrm{G} 34$ have also been identified.$^{19} \mathrm{It}$ is possible that the inflammation of the antral mucosa induced by $H$ pylori infection disturbs the intracellular processing of gastrin by the antral $\mathrm{G}$ cells.

There have been conflicting reports concerning the form of gastrin that is increased in $H$ pylori infection. Beardshall et $a l^{20}$ have reported that the increased gastrin response to gastrin releasing peptide in $H$ pylori infection is the result of increased G17. Graham et al, ${ }^{21}$ however, have claimed that the exaggerated meal stimulated gastrin response caused by $H$ pylor is the result of an increase in biologically inactive progastrin. To clarify this, we have examined the different circulating forms of gastrin in duodenal ulcer patients, basally and in response to eating, and both before and after eradication of $H$ pylori.

\section{Subjects and methods}

\section{PATIENTS}

Thirteen patients (three women, age range 25-64 years) with a history of duodenal ulceration were studied. $H$ pylori infection was confirmed in each by microscopy of endoscopic antral biopsy tissue, urease slide test (CLO-test) of antral biopsy tissue, and positive ${ }^{14} \mathrm{C}$-urea breath test. All patients stopped taking any acid inhibitory agents at least two weeks before entering the study and none had received bismuth preparations in the past.

\section{METHODS}

The patients reported at $0900 \mathrm{~h}$ after an overnight fast. Three venous blood samples $(10 \mathrm{ml}$ each) were taken over 30 minutes for fasting gastrin estimation. The patients then drank over 5 minutes a peptone meal consisting of two beef 

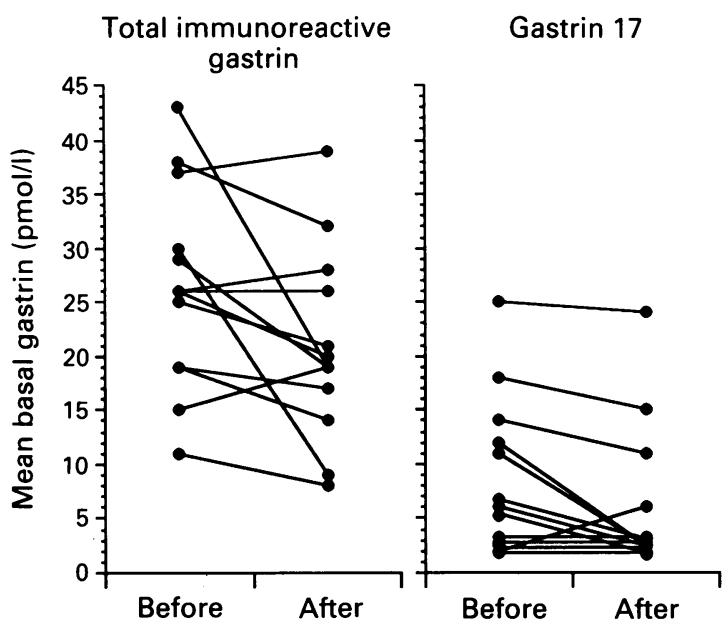

$(p<0.05)$ $(p<0.001)$
Gastrin 34

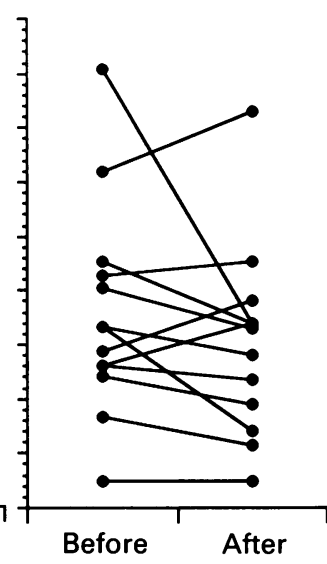

(NS)
Figure 1: Fasting serum concentrations of total immunoreactive gastrin (IRG) (R98), gastrin 17 (GP168), and gastrin 34 (subtraction assay) before and one month after eradication of Helicobacter pylori infection. cubes (OXO Ltd, Croydon, England) dissolved in $200 \mathrm{ml}$ water at $60^{\circ} \mathrm{C}$. A blood sample was taken five minutes after completing the drink and further samples were taken at 10 minute intervals for 90 minutes.

Patients then received a three week course of tripotassium dicitrato-bismuthate (De-Nol) $(120$ $\mathrm{mg}$ four times daily), metronidazole $(400 \mathrm{mg}$ three times daily), and amoxycillin (500 $\mathrm{mg}$ three times daily). One month after completing this treatment, the ${ }^{14} \mathrm{C}$-urea breath test was repeated to assess eradication of the infection. At this time the basal and meal stimulated gastrin concentrations were reassessed as described above.

\section{ANALYSIS}

The venous blood samples were allowed to clot over 10 minutes and the serum separated and stored at $-20^{\circ} \mathrm{C}$. Preliminary studies were undertaken in which random blood samples were obtained from 15 subjects and processed as serum, EDTA plasma, and lithium heparin plasma. These showed no statistical difference in

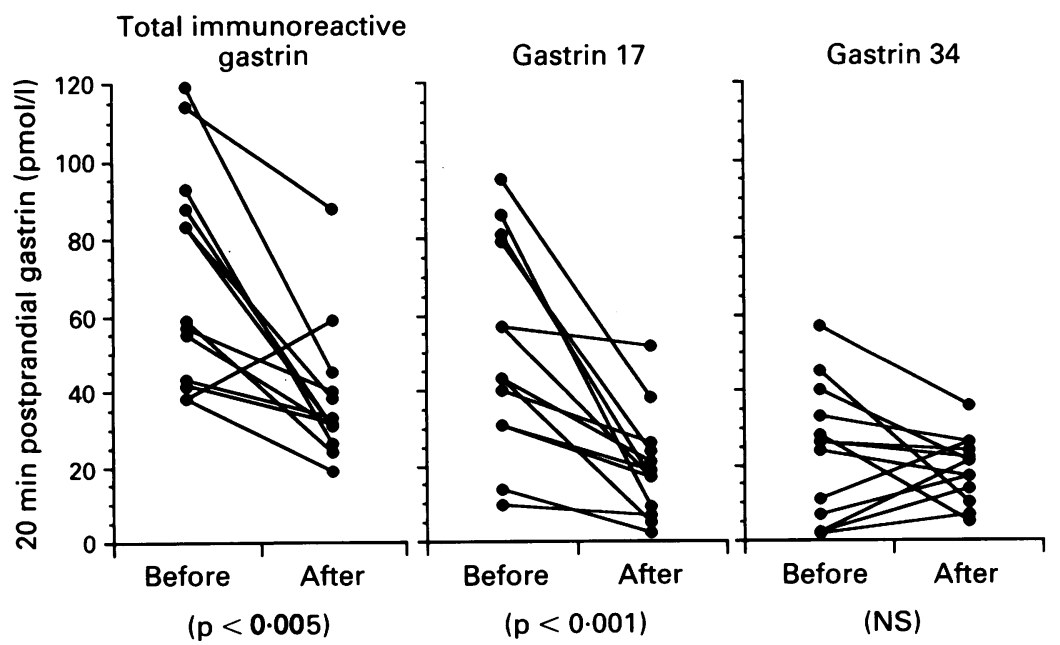

Figure 2: Meal stimulated serum concentrations of total immunoreactive gastrin (IRG) (R98), gastrin 17 (GP168), and gastrin 34 (subtraction assay) before and one month after eradication of Helicobacter pylori. the concentrations of the various forms of gastrins between the different methods of sample preparation.

The gastrin measurements were performed by standard radioimmunoassay techniques using three antisera, R98, GP168, and R526.

Antisera R98 was raised in rabbit to synthetic unsulphated human gastrin 2-17 coupled to chicken egg albumen using glutaraldehyde. ${ }^{22}$ It binds component I, G34, G17, and G14 in sulphated and unsulphated forms with equimolar potency. Cross reaction with cholecystokinn $(\mathrm{CCK})$ is $<0.00005$. The coefficient of interassay variation is $3.8 \%$ at $10 \mathrm{pmol} / \mathrm{l}, 3.3 \%$ at $20 \mathrm{pmol} / 1$, and $5 \cdot 4 \%$ at $40 \mathrm{pmol} / 1$.

Antisera GP168 was raised in guinea pig to synthetic human gastrin fragment $1-13$ of G17 coupled to chicken egg albumen using carbodiimide. It binds G17 in the sulphated and unsulphated forms with equimolar potency and also fragments $1-6$ and $1-13$ of G17. It does not bind component I, G34, or G14 and shows no cross reaction with CCK. The coefficient of interassay variation is $10 \cdot 1 \%$ at $10 \mathrm{pmol} / 1,7 \cdot 3 \%$ at $20 \mathrm{pmol} / 1$, and $3 \cdot 8 \%$ at $40 \mathrm{pmol} / 1$.

Antisera R526 was raised in rabbit to synthetic human gastrin fragment 1-17 of G34, coupled to chicken egg albumen using glutaraldehyde. It binds G34 in the sulphated and unsulphated forms and also binds $\mathrm{N}$-terminal fragments of G34. It does not bind G17 and G14. The coefficient of interassay variation is $12 \cdot 1 \%$ at 10 $\mathrm{pmol} / \mathrm{l}, 8 \cdot 5 \%$ at $20 \mathrm{pmol} / 1$, and $6 \cdot 2 \%$ at $40 \mathrm{pmol} / 1$.

The tracer used with both R98 and GP168 antisera was mono-iodinated (Leu15) human G17. The detection limit of both assays was $<2 \cdot 4$ $\mathrm{pmol} / \mathrm{l}$ as used routinely. The tracer used with R526 was mono-iodinated human G34. The detection limits of the assay was 5 pmol. All specimens were assayed in at least two dilutions and samples taken before and after eradication were assayed within the same batch.

G34 was assayed using antisera R526 in only eight patients in order to preserve sufficient sample for chromatographic studies. G34 was estimated using subtraction of G17 (GP168) from total gastrins (R98) in all 13 patients. The interassay variation for the subtraction assay is $10.4 \%$ at $20 \mathrm{pmol} / 1$, as determined by repeated measurements of clinical samples.

Chromatographic analysis was performed on serum samples obtained 20 minutes postprandially before and after eradication of $H$ pylori in six patients. This was undertaken to determine the contribution of G17 and G34 to the total immunoreactive gastrin in the presence and absence of $H$ pylori. The $2.5 \mathrm{ml}$ samples were applied to a G50 superfine column $(0.9 \times 100$ $\mathrm{cm})$. The samples were eluted using phosphate buffer $0 \cdot 1 \mathrm{M} \mathrm{pH} 7 \cdot 2$ that contained human albumen $0 \cdot 1 \mathrm{~g} \%$ (RIA grade). The flow rate was $4 \mathrm{ml} /$ hour. All eluates were assayed with the three assays described above. Recovery of gastrins from the column was $>80 \%$.

The mean value of the fasting samples obtained at 15 minutes and immediately before the meal was taken as the basal gastrin value. Statistical analysis was performed by means of the Wilcoxon rank sum test for paired data.

The study was approved by the Western 


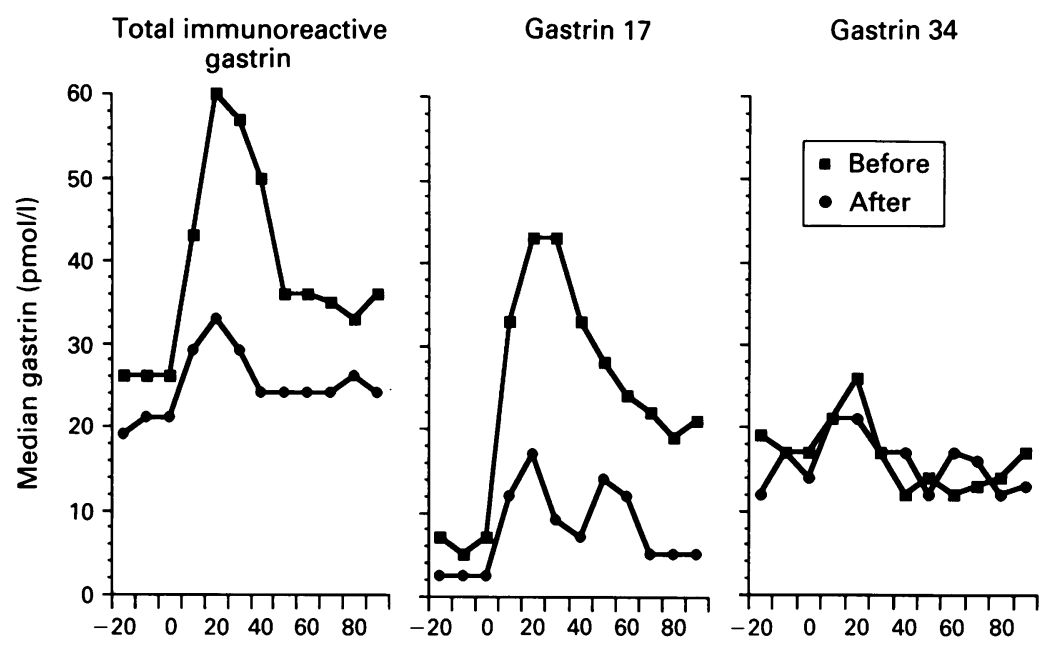

Figure 3: Median serum concentrations of total immunoreactive gastrin (IRG) (R98), gastrin 17 (GP168), and gastrin 34 (subtraction assay) basally and in response to a meal, before and one month after eradication of Helicobacter pylori. The meal was begun at time 0 . Thirteen patients were studied. after eradication rose from $<2 \cdot 4 \mathrm{pmol} / \mathrm{l}(<2 \cdot 4$ $23)$ to $17 \mathrm{pmol} / 1(<2 \cdot 4-52)(\mathrm{p}<0.0001)$. In the presence of $H$ pylori, the median G34 concentration was $16 \mathrm{pmol} / \mathrm{l}(0-40)$ basally and $26 \mathrm{pmol} / \mathrm{l}$ $(0-57) 20$ minutes postprandially $(\mathrm{p}=0 \cdot 2)$ as determined by subtraction assay, and $15 \mathrm{pmol} / \mathrm{l}$ (2-36) basally and $13 \mathrm{pmol} / \mathrm{l}(6-42)$ postprandially measured by antisera R526. After eradication of $H$ pylori, the median $\mathrm{G} 34$ was $16.5 \mathrm{pmol} / \mathrm{l}$ (0-36) basally compared with $21 \mathrm{pmol} / \mathrm{l}$ (5-36) postprandially $(\mathrm{p}=0.06)$ as determined by subtraction assay and $10 \mathrm{pmol} / \mathrm{l}(2-30)$ basally and 15 $\mathrm{pmol} / \mathrm{l}(6-30)$ postprandially by antisera R526.

In the fasting state, $\mathrm{G} 17$ represented only $23 \%$ of the total immunoreactive gastrin in molar terms in the presence of $H$ pylori and this fell to less than $10 \%$ after eradication of the infection. In contrast, the 20 minute postprandial total immunoreactive gastrin consisted of $72 \%$ G17 in the presence of $H$ pylori and 52\% G17 after eradication.

Chromatographic analysis of the postprandial serum from the six patients indicated that G17 and $\mathrm{G} 34$ comprised more than $90 \%$ of the total immunoreactive gastrin detected by antisera $\mathrm{R} 98$ both before and after eradication of $H$ pylori (Fig 4) (Table). Only a minor contribution was made by component I and G14.

Further analysis of the eluate using all three antisera indicated that a minor contribution was made also by a N-terminal 1-13 of G17 identified by the GP168 antiserum. This co-elutes with G14 (detected by R98) (Fig 5). No other aberrent forms were observed.

\section{Discussion}

This study indicates that in duodenal ulcer patients circulating gastrin consists almost entirely of G17 and G34 in both the presence and absence of $H$ pylori infection. This is consistent with previous studies which have shown that more than $90 \%$ of gastrin in serum consists of G17 and G34 in both duodenal ulcer patients and healthy volunteers. ${ }^{2324}$ The current study also shows that the increased serum total immunoreactive gastrin in $H$ pylori infection is entirely the result of an increase in G17, with no change in G34. The former is mainly antral in origin, whereas G34 is preferentially released from the duodenum. ${ }^{2325-28}$ The selective increase in the form of gastrin produced by the antrum is from $59 \mathrm{pmol} / \mathrm{l}(38-114)$ to $33 \mathrm{pmol} / \mathrm{l}(19-88)$ $(\mathrm{p}<0.005)$, and representing a median fall of $43 \%$ (Fig 2). This was again explained by a fall in the $\mathrm{G} 17$ concentration from $43 \mathrm{pmol} / \mathrm{l}(9-95)$ to $17 \mathrm{pmol} / \mathrm{l}(<2.4-52)(\mathrm{p}<0.001)$ representing a median fall of $60 \%$. The median 20 minute postprandial G34 concentration was similar before (26 pmol/l, range $0-57)$ and after (21 $\mathrm{pmol} / \mathrm{l}, 7-36)$ eradication of $H$ pylori as determined by subtraction assay, and also similar before (13 pmol/1, 6-42) and after (15 pmol/1, 6-30) as measured by antisera R526.

In both the presence and absence of $H$ pylori, the rise in total immunoreactive gastrin with eating was predominantly caused by an increase in G17 (Fig 3). In the presence of $H$ pylori, the median G17 concentration rose from a basal value of $6 \mathrm{pmol} / \mathrm{l}(<2 \cdot 4-25)$ to $43 \mathrm{pmol} / \mathrm{l}(9-95)$ $(\mathrm{p}<0.0001)$ at 20 minute postprandially, and
Chromatographic analysis of postprandial serum gastrin in six patients before and after eradication of Helicobacter pylori. patients before and after eradication of Helicobacter pylor
Values of the individual gastrins are express as pmol/l. The total immunoreactive gastrin the eluate from the $G 50$ column was detected by antisera $R 98$

\begin{tabular}{|c|c|c|c|c|c|}
\hline $\begin{array}{l}\text { Patient } \\
\text { no }\end{array}$ & H pylori & $\begin{array}{l}\text { Component } \\
\text { I }\end{array}$ & $G 34$ & G17 & GI4 \\
\hline \multirow[t]{2}{*}{1} & Before & 7 & 127 & 141 & 19 \\
\hline & After & $\begin{array}{l}1 \\
9\end{array}$ & 81 & 15 & 2 \\
\hline 2 & $\begin{array}{l}\text { Before } \\
\text { After }\end{array}$ & $\begin{array}{l}9 \\
7\end{array}$ & $\begin{array}{l}76 \\
67\end{array}$ & $\begin{array}{r}112 \\
34\end{array}$ & $\begin{array}{r}11 \\
5\end{array}$ \\
\hline 3 & Before & $\begin{array}{l}5 \\
4\end{array}$ & $\begin{array}{l}38 \\
36\end{array}$ & $\begin{array}{l}64 \\
40\end{array}$ & $\begin{array}{l}7 \\
5\end{array}$ \\
\hline 4 & Before & $\begin{array}{l}3 \\
3\end{array}$ & $\begin{array}{l}55 \\
56\end{array}$ & $\begin{array}{l}88 \\
49\end{array}$ & 10 \\
\hline \multirow[t]{2}{*}{5} & Before & 9 & 106 & $\begin{array}{r}49 \\
187\end{array}$ & 18 \\
\hline & After & 8 & 84 & 99 & 11 \\
\hline \multirow[t]{2}{*}{6} & Before & 2 & 48 & 77 & 10 \\
\hline & After & 1 & 43 & 24 & 6 \\
\hline
\end{tabular}




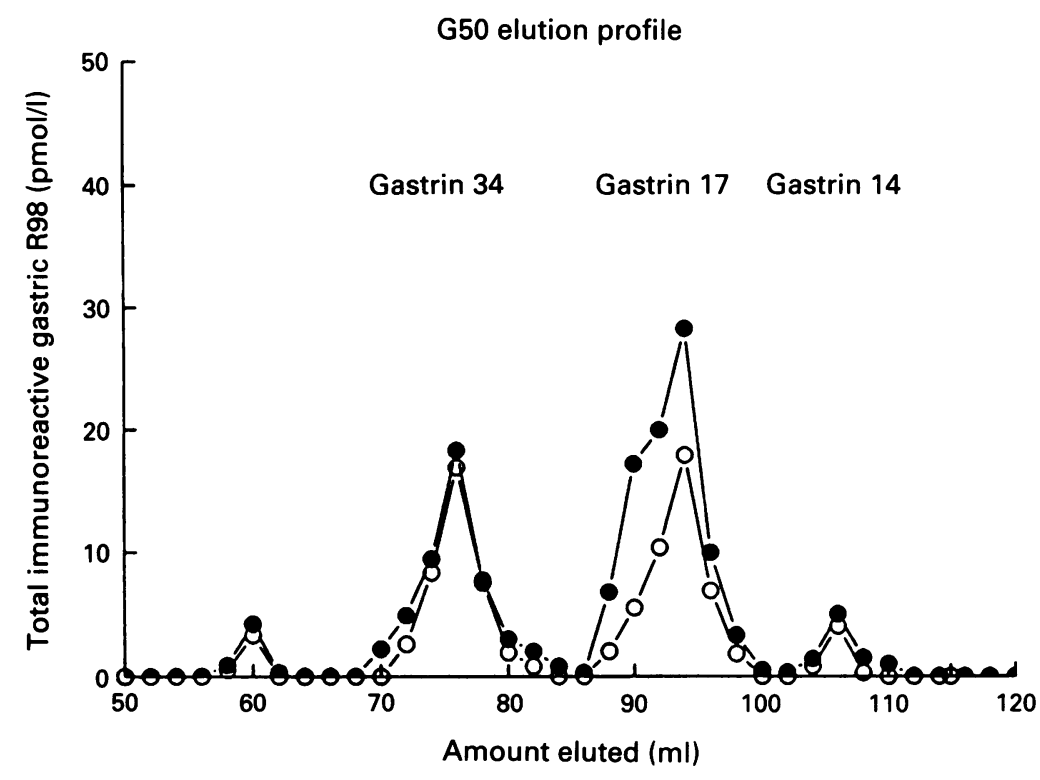

Figure 4: Chromatography of postprandial serum in a representative patient before $(O)$ and after $(\mathrm{O})$ eradication of Helicobacter pylori. The total immunoreactive gastrin in the eluate from the G50 column was detected by antisera $R 98$.

consistent with the finding that $H$ pylori infection predominantly affects this region of the stomach.

Our finding that fasting serum gastrin consists mainly of G34 is consistent with previous reports. ${ }^{2329}$ These earlier studies were performed before the recognition of $H$ pylori and most of the patients included would have had the infection. Our present study indicates that in the presence of $H$ pylori infection, fasting serum gastrin consists of $77 \%$ G34 whereas in the absence of $H$ pylori it consists almost exclusively of G34 $(98 \%)$. It is possible that re-examination of these patients at a later date when any persisting antral gastritis has resolved may indicate that fasting gastrin consists entirely of G34. Our finding also confirms previous reports that postprandial serum gastrin consists of approximately equivalent concentrations of $\mathrm{G} 17$ and G34..$^{23} 29$ The ratio of G17:G34, however, is greater in the presence of the infection $(72 \% \mathrm{G17})$ than in its absence (52\%). The change in the G17:G34 ratio as a result of $H$ pylori infection is explained by the infection selectively increasing the G17 concentration.

It has previously been recognised that eating produces a more noticeable rise in G17 than in G34. ${ }^{23} 29$ We found no statistically significant rise in G34 postprandially, either in the presence or absence of $H$ pylori. In contrast, there was a noticeable rise in $\mathrm{Gl} 7$ both before and after eradication of the infection. Our finding is similar to that of Walker $e t a l$, who reported that the rise in gastrin with eating was solely the result of a rise in G17 in duodenal ulcer patients. ${ }^{29}$ In an earlier study by Dockray and Taylor, however, a rise in both G17 and G34 was noted after eating in duodenal ulcer patients. ${ }^{30}$ The reason for these different findings is unclear but may be related to the different forms of meal used.

Most investigators have observed that $H$ pylori infection causes a greater percentage increase in the postprandial gastrin than fasting gastrin..$^{2-6}$ This can now be explained by the fact that $H$ pylori causes a selective increase in $\mathrm{G} 17$, which is the form of hormone which rises most with eating. Though $H$ pylori also raises $\mathrm{G} 17$ several fold in the fasting state, this only causes a minor increase in fasting serum gastrin which consists predominantly of $\mathrm{G} 34$.

The mechanism by which $H$ pylori infection stimulates the release of $\mathrm{G} 17$ is not known. It was suggested by Levi et al that the ammonia produced by the organism's urease would prevent the suppression of antral gastrin release by luminal acid. " This seems unlikely, however, as earlier studies have shown that neither increasing, ${ }^{7}$ inhibiting, ${ }^{8}$ or completely suppressing ${ }^{9}$ $H$ pylori urease activity in vivo changes the serum gastrin. In addition, $H$ pylori infection has been shown to change gastrin to a similar degree at acidic and neutral $\mathrm{pH} .{ }^{10}$ The time course of resolution of the hypergastrinaemia during antibacterial treatment indicates that it is more closely related to resolution of the antral gastritis than to suppression of bacterial urease activity. ${ }^{921}$

It has been suggested that the processing of gastrin in duodenal ulcer patients may be altered ${ }^{17183132}$ and that aberrent forms of gastrin that are immunoreactive but not bioactive may circulate, thus obscuring any correlation
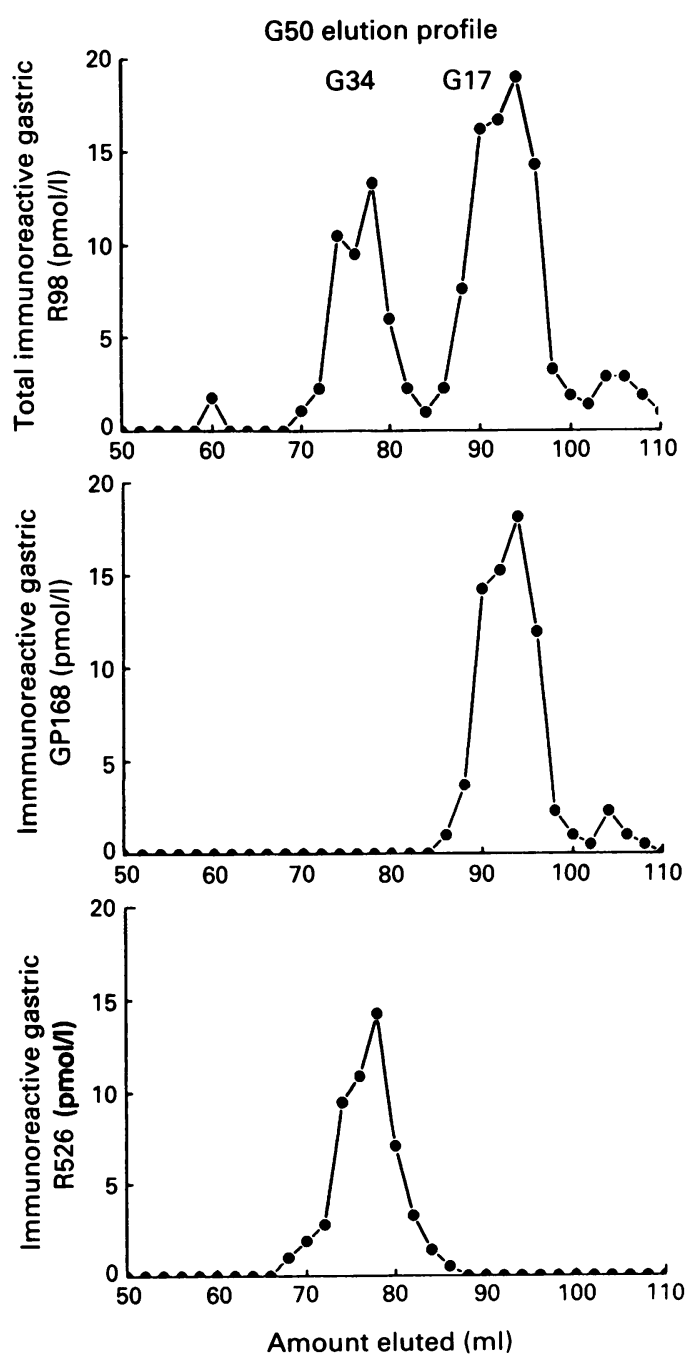

Figure 5: Chromatography of postprandial serum from a Helicobacter pylori positive duodenal ulcer patient. The eluate from the G50 column was examined using antisera $R 98$ (total immunoreactive gastrins) GP168 (N-terminal immunoreactive gastrin) and R526 (immunoreactive G34) 
between gastrin and gastric acid secretion. Our present study clearly indicates that any contribution made by abnormal forms of gastrin is minimal and that the gastrin which is increased in the presence of $H$ pylori infection is G17.

In view of the fact that eradication of $H$ pylori infection noticeably lowers postprandial G17 concentrations, one would expect an accompanying decrease in meal stimulated acid secretion. G17 and G34 are equipotent in molar terms with respect to stimulating acid secretion..$^{33} \mathrm{At}$ one month after eradication of $H$ pylori in duodenal ulcer patients we observed a more marked rise in postprandial $\mathrm{pH}$ consistent with a reduced acid response to the meal. ${ }^{34}$ Using intragastric titration, however, Moss et al ${ }^{12}$ have been unable to show a fall in meal stimulated acid secretion after anti- $H$ pylori treatment. The lack of fall in acid secretion despite a considerable fall in biologically active gastrin could be explained by $H$ pylori altering the parietal cell sensitivity to gastrin. $H$ pylori has been shown to produce a factor which inhibits parietal cells in vitro ${ }^{35}$ and hypochlorhydria may be a feature of the acute infection. ${ }^{36}$ We have shown, however, that there is no change in parietal cell sensitivity to gastrin after eradication of $H$ pylori in duodenal ulcer patients. ${ }^{37}$

The finding of our present study that eradication of $H$ pylori reduces noticeably a biologically active form of gastrin, together with our previous finding that this is not accompanied by reduced parietal cell sensitivity to the hormone, strongly suggests that there should be an accompanying fall in gastrin mediated acid secretion. The failure of studies to show this clearly is probably related to the technical difficulties involved in measuring meal stimulated acid secretion.

This work was supported by a grant from the Biomedical Research Committee of the Scottish Home and Health Department and by the Research Support Group of the Greater Glasgow Health Board. G Mulholland was supported by a grant from the Eastern Health and Social Services Board of Northern Ireland.

The technical assistance of the Western Infirmary Departmen of Nuclear Medicine, and the secretarial services of Mrs Dorothy Ronney are gratefully acknowledged.

This work was presented at the 1992 Spring Meeting of the British Society of Gastroenterology and published in abstract form in Gut.

1 Oderda G, Vaira D, Holton J, Ainley C, Altare F, Ansaldi N Amoxycillin plus tinidazole for Campylobacter pylori
gastritis in children: assessment by serum IgG antibody, gastritis in children: assessment by serum IgG antibody
pepsinogen I, and gastrin levels. Lancet $1989 ; \mathrm{i}: 690-2$.

2 Levi S, Bearsdhall K, Swift I, Foulkes W, Playford R, Ghosh $\mathrm{P}$, et al. Antral Helicobacter pylori, hypergastrinaemia and duodenal ulcers: effect of eradicating the organism. $B M$ 1989; 299: 1504-5.

3 McColl KEL, Fullarton GM, Chittajallu R, El Nujumi AM, Macdonand AMI, Dahill SW,et al. Plasma gastrin, daytime intragastric $\mathrm{pH}$, and nocturnal acid output before and at 1 and 7 months after eradication of Helicobacter pylori in duodenal ulcer subjects. Scand f Gastroenterol 1991; 26 (no 3): 339-46.

4 Graham DY, Opekum A, Lew GM, Evans DJ, Klein PD, Evans DG. Ablation of exaggerated meal-stimulated gastrin release in duodenal ulcer patients after clearance of Helicobacter (Campylobacter) pylori infection. $A m \mathcal{F} G$ astroenterol 1990; 85 (no 4): 394-8.

5 Smith JTL, Pounder RE, Nwokolo CU, Lanzon-Miller S, Evans DG, Graham DY, et al. Inappropriate hypergastrinaemia in asymptomatic healthy subjects infected with Helicobacter pylori. Gut 1990; 31: 522-5.

6 Chittajallu RS, Ardill JES, McColl KEL. The degree of hypergastrinaemia induced by Helicobacter pylori is the same in duodenal ulcer patients and asymptomatic volunteers. Eur $\mathcal{F}$ Gastroenterol Hepatol 1992; 4: 49-53.

7 Chittajallu RS, Neithercut WD, Macdonald AMI, McCol KEL. Effect by increasing Helicobacter pylori ammonia production of urea infusion on plasma gastrin concentrations. Gut 1991; 32: 21-4.
8 Nujumi AMEl, Dorrian CA, Chittajallu RS, Neithercut WD, McColl KEL. Effect of inhibition of Helicobacter pylor urease activity by acetohydroxamic acid on serum gastrin in duodenal ulcer subjects. Gut 1991; 32: 866-70.

9 Chittajallu RS, Dorrian CA, Neithercut WD, Dahill S, McColl KEL. Is Helicobacter pylori associated hypergastrinaemia due to the bacterium's urease activity or the antral gastritis? Gut 1991; 32: 1286-90.

10 Chittajallu RS, Neithercut WD, Ardill JES, McColl KEL. $H$ pylori-related hypergastrinaemia is not due to elevated $H$ pylori-related hypergastrinaemia is not due to elevated
antral surface $\mathrm{pH}$ : studies with antral alkalinization. Scand $\mathcal{F}$ antral surface pH: studies with

11 Levi S, Beardshall K, Haddad G, Playford R, Ghosh P, Galam J. Campylobacter pylori and duodenal ulcers: the gastrin link. Lancet 1989; i: 1167-8.

12 Moss S, Ayesa K, Li SK, Calam J. Gastrin, gastric acid and pepsin responses during intragastric titration in duodenal ulcer patients; effect of suppressing Helicobacter pylori. Gut 1991; 32: A1206-7.

13 Rehfeld JF. Three components of gastrin in serum. Biochim Biophys Acta 1972; 285: 364-72.

14 Gregory RA, Tracy HJ. Isolation of two big gastrins from Zollinger Ellison tumour tissue. Lancet 1972; ii: 797-9.

15 Gregory RA, Tracy $\mathrm{HJ}$. The constitution and preparation of two gastrins extracted from hog antral mucosa. Gut 1964; 5: 103-17.

16 Rehfeld JF, Stadil F. Gell filtration studies on immunoreactive gastrin in serum from Zollinger Ellison patients. Gut 1973;
14: 369-73.

17 Akai H, Toyota T, Goto Y, Yanahara C, Yanahara N. Coexistence and co-release of gastrin-34 N-terminal with gastrin-17 immunoreactivity in rat stomach. Biomedical Research 1990; 11 (suppl): 319-26.

18 Kothary PC, Vinik AI. NH2 terminus of gastrin-17 in duodenal ulcer disease. Identification of progastrin-17. Biochem Biophy Res Commun 1987146 (2): 884-8.

19 Pauwela S, Dockray GJ. Identification of NH2 fragments of big gastrin in plasma. Gastroenterology 1982; 82: 56-61.

20 Beardshall K, Moss S, Gill J, Levi S, Ghosh P, Playford RJ, et al. Suppression of $H$ pylori reduces gastrin releasing et al. Suppression of $H$ pylori reduces gastrin releasing peptide stimulation gastrin

21 Graham DY, Lew GM, Go MF, Genta RM, Klein PD, Rehfeld JF. Helicobacter pylori infection and gastrin release: mechanism and relevance. Gastroenterology 1992; 102: A76.

22 Ardill J. Radioimmunoassay of GI hormones. Clinics in Endocrinology and Metabolism 1979; 8: 265-80.

23 Lamers CB, Walsh JH, Jansen JB, Harrison AR, Ippoliti AF, Van Tongeren JH. Evidence that gastrin 34 is preferentially released from the human duodendum. Gastroenterology 1982; 83: 233-39.

24 Dockray GJ. Gastrointestinal hormones II. Gastrin cholecystokinin, and secretin. In: Gray CH, James VHT, eds. Hormones in blood, 3rd ed. London: Academic Press, 1979.

25 Calam J, Dockray GJ, Walker R, Tracey HJ, Owens D. Molecular forms of gastrin in peptic ulcer: comparison of serum and tissue concentrations of G-17 and G-34 in gastric and duodenal ulcer subjects. Eur $\mathcal{F}$ Clin Invest 1980; 10: 241-7.

26 Malmstrom J, Stadil F, Rehfeld F. Gastrins in tissue. Concentration and component pattern in gastric, duodenal, and jejunal mucosa of normal human subjects and patients with duodenal ulcer. Gastroenterology 1976; 70: 697-703.

27 Petersen B, Andersen BN. Abnormal processing of antral gastrin in active duodenal ulcer disease. Eur $\mathcal{F}$ Clin Invest $1984 ; 14: 214-8$.

28 Creutzfeldt W, Arnold R, Creatzfeldt C, Track NS. Mucosal gastrin concentration, molecular forms of gastrin, number and ultrastructure of G cells in patients with duodenal ulcer. Gut 1976; 17: 745-54.

29 Walker K, Pinchbeck B, Mahachai V, Simpson I, Kirkeikis P, Zuk L, et al. Postprandial changes in serum concentrations
of gastrin-17, gastrin-34, and total gastrin in patients with of gastrin-17, gastrin-34, and total gastrin in patients with
duodenal or gastric ulcers and in normal subjects. Clin Ther duodenal or gast

30 Dockray GJ, Taylor IL. Different forms of gastrin in peptic ulcer. Adv Exp Med Biol 1978; 106: 91-6.

31 Iwanaga T, Kusumoto Y, Fujita T, Yanahara C, Mochizuki T, Yanahara $\mathrm{N}$. Immunocytochemical localization of the different gastrin forms in the pyloric antrum. Biomedical Res $1980 ; 1: 316-20$.

32 Petersen B, Andersen B. Abnormal processing of antral gastrin in the active duodenal ulcer. Eur f Clin Invest 1984; 14: 214 18.

33 Eysselein VE, Maxwell V, Reedy T, Wunsch E, Walsh JH. Similar acid stimulatory potencies of synthetic human big
and little gastrins in man. $\mathcal{F}$ Clin Invest $1984 ; 73$ (5): 1284 and

34 McColl KEL, Fullarton GM, Nujumi AM, Macdonald AM, Brown IL, Hilditch TE. Lowered gastrin and gastric acidity after eradication of campylobacter pylori in duodenal ulcer. Lancet 1989; ii: 499-500.

35 Cave DR, Vargas M. Effect of a Campylobacter pylori protein on acid secretion by parietal cells. Lancet 1989 ; ii: 187 .

36 Sobala GM, Crabtree JE, Dixon MF, Schorah CJ, Taylor JD, Rathbone BJ, et al. Acute Helicobacter pylori infection: clinical features, local and systemic immune response gastric mucosal histology, and gastric juice ascorbic acid concentrations. Gut 1991; 32: 1415-8.

37 Chittajallu RS, Howie CA, McColl KEL. Effect of Helicobacter pylori on parietal cell sensitivity to pentagastrin in duodenal ulcer subjects. Scand $\mathcal{F}$ Gastroenterol 1992; 27 $857-62$. 